\title{
Biphasic Ni-Catalyzed Ethylene Oligomerization in lonic Liquids
}

\author{
V. Lecocq and $\mathrm{H}$. Olivier-Bourbigou \\ Institut français du pétrole, IFP, BP 3, 69390 Vernaison - France \\ e-mail: helene.olivier-bourbigou@ifp.fr
}

\begin{abstract}
Résumé - Oligomérisation biphasique de l'éthylène catalysée par les complexes du nickel dans les liquides ioniques - Les complexes diimines du nickel activés par un aluminoxane dans les liquides ioniques chloroaluminates forment des systèmes très actifs d'oligomérisation ou de polymérisation de l'éthylène en fonction de l'encombrement du ligand diimine. Le $\mathrm{Ni}(0)$ peut également être activé par un acide de Brönsted dans différents liquides ioniques non chloroaluminates. La nature du liquide ionique ainsi que la présence d'un ligand azoté ou non modifient considérablement les performances catalytiques de ces systèmes. Les produits oléfiniques de la réaction sont très faiblement solubles dans les liquides ioniques et peuvent être séparés par décantation. Le liquide ionique contenant le nickel peut être recyclé.
\end{abstract}

\begin{abstract}
Biphasic Ni-Catalyzed Ethylene Oligomerization in Ionic Liquids - Diimine nickel complexes activated with aluminoxane in chloroaluminate ionic liquids are highly active catalysts either for the biphasic ethylene oligomerization or for polymerization depending on the bulkiness of the diimine ligand. The activation of $\mathrm{Ni}(\mathrm{O})$ with a Brönsted acid in different non-chloroaluminate ionic liquids is also reported. The nature of the ionic liquid and the presence or not of a nitrogen ligand affect significantly the catalytic performances. The olefinic products are weakly soluble in ionic liquids and can be separated from the catalytic ionic phase by simple decantation. The nickel catalysts are immobilized and stabilized in the ionic liquids and can be recycled.
\end{abstract}




\section{ABREVIATIONS}

$\begin{array}{ll}\text { BMI } & \text { 1-butyl-3-methylimidazolium } \\ \text { BMPyrro } & N, N \text { '-butyl-methylpyrrolidinium } \\ \text { NTf }_{2} & \text { bis[(trifluoromethane)sulfonyl]amidure } \\ \text { OTf } & \text { trifluoromethanesulfonate } \\ \text { BAr }_{F} & \left.\text { B }\left[3,5-\left(\mathrm{CF}_{3}\right)_{2} \mathrm{C}_{6} \mathrm{H}_{3}\right]_{4}\right)\end{array}$

\section{INTRODUCTION}

Hydrocarbon cracking processes, such as steam cracking or catalytic cracking, and Fischer-Tropsch synthesis produce significant amount of light olefins $\left(\mathrm{C}_{2}\right.$ to $\mathrm{C}_{5}$ fractions $)$. Dimerization, co-dimerization or polymerization reactions are widely used on industrial scale either to provide chemicals of high value or to upgrade by-product olefinic stream [1]. The ethylene oligomerization is one of the major industrial process for the production of linear alpha olefins (LAO) [2]. Depending on their chain length, these alpha olefins are used either as co-monomers (C4-C8) in the polymerization of ethylene to give linear low-density polyethylene (LLDPE) or as intermediates for the preparation of plasticizers, lubricants or surfactants [3]. The largest industrial LAO processes via ethylene oligomerization are BP Amoco (alkylaluminium), Chevron-Phillips ( $\mathrm{AlEt}_{3}$ ) and Shell (SHOP process: biphasic process based on Ni catalyst). Recently, IFP (Institut Français du Pétrole) has developed the Alphaselect process, a new process which can produce high selectivity towards $\mathrm{C} 4-\mathrm{C} 10$ alpha olefins [4]. However, many efforts are still devoted to the development of selective ethylene oligomerization catalytic systems, specially with single site nickel complexes containing bidentate or tridentate chelating ligands $[\mathrm{P}-\mathrm{P}],[\mathrm{P}-\mathrm{N}],[\mathrm{P}-\mathrm{O}]$, $[\mathrm{N}, \mathrm{O}],[\mathrm{N}-\mathrm{N}]$ or $[\mathrm{N}, \mathrm{E}, \mathrm{N}]$ with $\mathrm{E}=\mathrm{O}, \mathrm{S}$ or $\mathrm{N}[5]$.

Nitrogen ligands, namely alpha diimines associated with nickel and with a co-catalyst, such as methyl aluminoxane (MAO), give particularly active systems for the oligomerization or the polymerization of ethylene, depending on the steric hindrance of ortho and ortho' substituants of the aromatic $\alpha$-diimine ligand. For bulky substituants such as isopropyl, Ni complexes lead to ethylene polymerization and with less steric hindrance substituants such as hydrogen or ortho methyl, linear $\alpha$-olefins are mainly obtained [6]. The superiority of these systems lies in their great versatility, in their high activities and selectivities, and also in their ability to copolymerize olefins and polar substrates (acrylates).

Industrial olefin oligomerization processes catalyzed by coordination complexes are generally performed in homogeneous systems [1, 4]. The organometallic active catalyst is dissolved in the reaction medium and operates in a liquid phase, with or without solvent. The catalyst is generally neutralized at the output of the reactor and is not recycled. However, costly catalysts may need to be recycled to make industrial processes more economically viable. Shell Higher
Olefin Process (SHOP) was the first industrial catalytic process to benefit from two-phase liquid-liquid technology [2]. The P-O chelate Ni complex operates in butanediol in which the $\alpha$-olefins produced are only partially soluble. The catalytic phase can be separated from the reaction products by decantation. However, the majority of oligomerization active catalysts involves organometallic species which are considered to be prone to hydrolysis. Moreover, the coordination sites of the complexes can be blocked by the solvent. Non-protic weakly coordinating solvents should therefore be preferred. In regards of these requirements, ionic liquids provide good alternative solvents [7].

In the beginning of the 90's, Chauvin et al. [8] showed that oligomerization of olefins could be performed by nickel complexes immobilized in chloroaluminate ionic liquids, thus inventing the basis of the IFP Difasol process [9]. The oligomerization of ethylene catalyzed by nickel complexes in chloroaluminate [10] or associated with bidentate chelate [P$\mathrm{O}]$ ligands in non-chloroaluminate ionic liquids was later described [11].

In this contribution, we report results on the biphasic oligomerization of ethylene catalyzed by nickel complexes, associated or not with imine ligands, in chloroaluminate and non-chloroaluminate ionic liquids.

\section{EXPERIMENTAL SECTION}

All the synthesis and manipulations of nickel complexes and ionic liquids were carried out under an argon atmosphere using standard Schlenk techniques. Solvents were dried by distillation on sodium for toluene, diethyl ether and THF. $\mathrm{CaH}_{2}$ was used for methylene chloride and 1,1,1trichloroethylene. $\mathrm{K}_{2} \mathrm{CO}_{3}$ was used for acetone. MAO (Witco, $10 \mathrm{wt} \% \mathrm{Al}$ solution in toluene) was used as received. Ethylene (Air Liquide, 99.5\% purity) is dried over molecular sieves ( $3 \AA$ ) prior use. Methylimidazole and liquid anilines are purchased from Aldrich and were flash distilled before use in order to remove the coloured impurities. Solid anilines, $\mathrm{LiNTf}_{2}\left[\mathrm{NTf}_{2}=\mathrm{N}\left(\mathrm{CF}_{3} \mathrm{SO}_{2}\right)_{2}\right]$, butanedione and glyoxal, also purchased from Aldrich were used as received.

(DME) $\mathrm{NiCl}_{2}$ and $(\mathrm{DME}) \mathrm{NiBr}_{2}(\mathrm{DME}=$ dimethoxyethane $)$ were synthesized as previously described [12]. The ionic ether compound [RMI][NTf $\left.{ }_{2}\right]\left(\mathrm{R}=\left(\mathrm{CH}_{2}\right)_{2} \mathrm{OCH}_{3}\right)$ [13] and $\mathrm{H}(\mathrm{OEt})_{2} \mathrm{BAr}_{\mathrm{F}}\left(\mathrm{BAr}_{\mathrm{F}}=\mathrm{B}\left[3,5-\left(\mathrm{CF}_{3}\right)_{2} \mathrm{C}_{6} \mathrm{H}_{3}\right]_{4}\right)$ [14] were synthesized according to literature procedure. Ionic liquids, except chloroaluminates, were dried under vacuum $\left(10^{-2} \mathrm{mbar}\right)$ at $50^{\circ} \mathrm{C}$ to remove traces of water before use.

NMR analysis were performed on a Bruker AC $200 \mathrm{MHz}$. (s) stands for singlet, (d) doublet, t (triplet), q (quadruplet), (qt) quintuplet, (st) sextuplet and (m) multiplet.

Mass spectra (FAB mode) were performed at the SCACNRS (Chemin du Canal, Échangeur de Solaize, BP 22, 69390 Vernaison, France). Quantitative Gas Chromatographic 
(GC) analysis of reaction products were performed on a HP 5890 equipped with a FID detector and PONA capillary column (50 m length, $0.2 \mathrm{~mm}$ i.d., and film thickness of 0.5 $\mu \mathrm{m}$ ) operating at $35^{\circ} \mathrm{C}$ for $10 \mathrm{~min}$ then heating at $5^{\circ} \mathrm{C} \mathrm{min}^{-1}$ to $70^{\circ} \mathrm{C}$, stay at $70^{\circ} \mathrm{C}$ for $10 \mathrm{~min}$ then heating at $10^{\circ} \mathrm{C} \mathrm{min}^{-1}$ to $270^{\circ} \mathrm{C}$, stay at $270^{\circ} \mathrm{C}$ for $20 \mathrm{~min}$. Elemental analysis were made under inert atmosphere by Mikroanalytisches Labor Pascher (An der Pulvermühle 3, 53424 RemagenBandorf, Germany). Water content in ionic liquids is determined by Karl-Fischer coulometry (Metrohm 756 KF). Chloride content is determined by $\mathrm{AgNO}_{3}$ titration. This method permits the determination of chloride amount as low as $3 \times 10^{-3}$ mol. $\mathrm{L}^{-1}$.

\subsection{Oligomerization or Polymerization of Ethylene with $\mathrm{Ni}(0)$}

The reaction was performed in a $100 \mathrm{~mL}$ double-wall stainless steel reactor equipped with a magnetic stirrer $(750 \mathrm{rpm})$. The autoclave was dried under vacuum $\left(10^{-2} \mathrm{mbar}\right)$ at $90^{\circ} \mathrm{C}$ for 4 hours and then cooled to ambient temperature under ethylene (28 bars) pressure. After depressurization, a toluene solution of $\mathrm{Ni}(\mathrm{COD})_{2}$ was introduced and then $\mathrm{H}(\mathrm{OEt})_{2} \mathrm{BAr}_{\mathrm{F}}$ in $5 \mathrm{~mL}$ of ionic liquid. The autoclave was then pressurized to 10 bars, and the solution stirred for 5 minutes. A toluene solution of the ligand was eventually added. The reactor was then brought to the working pressure and continuously fed with ethylene using a reserve bottle placed on a balance to allow continuous monitoring of the ethylene uptake.

At the end of each test, the gas phase is quantified with a flow-meter and analyzed by GC. The liquid phase, cooled in the reactor at $-5^{\circ} \mathrm{C}$, is quickly flash distilled. The distilled products are quenched with cooled water and analyzed by GC. The results of the GC analysis are then compared to the weight of the ethylene consumed in order to obtain the mass balance.

\subsection{Oligomerization or Polymerization of Ethylene with Ni(II)}

The catalytic reaction is carried out in a similar way as previously described. After drying the reactor, the solution of MAO in toluene is first introduced and stirred under 5 bar of ethylene at the working temperature. Then, the suspension of the nickel complex in the ionic liquid is added under atmospheric pressure of ethylene. The reactor is then brought to the working pressure. The gaseous and liquid products are analyzed as described.

\subsection{Ionic Liquids Synthesis}

All the ionic liquids presented here are now commercially available, except [BMI] $\left[\mathrm{BAr}_{\mathrm{F}}\right]$.

\section{1-Butyl-3-methylimidazolium chloride [BMI][Cl]}

$\mathrm{N}$-methylimidazole (122 mL, $1.53 \mathrm{~mol})$ is dissolved in chlorobutane $(256 \mathrm{~mL}, 2.45 \mathrm{~mol})$ under an argon atmosphere. The solution is refluxed for $48 \mathrm{~h}$ and then, the biphasic medium is decanted. The lower phase is slowly added to $500 \mathrm{~mL}$ of toluene in order to precipitate the imidazolium chloride. The white solid is isolated by filtration, washed twice with $200 \mathrm{~mL}$ of cooled toluene and dried under vacuum $(198 \mathrm{~g}, 75 \%$ yield $)$.

NMR ${ }^{1} \mathrm{H}\left(\mathrm{CD}_{2} \mathrm{Cl}_{2}\right): 10.8(1 \mathrm{H}, \mathrm{s}), 7.5(2 \mathrm{H}, \mathrm{d}), 4.2(2 \mathrm{H}, \mathrm{t})$, $4.0(3 \mathrm{H}, \mathrm{s}), 1.8(2 \mathrm{H}, \mathrm{qt}), 1.3(2 \mathrm{H}, \mathrm{st}), 0.9(3 \mathrm{H}, \mathrm{t})$.

NMR ${ }^{13} \mathrm{C}\left(\mathrm{CD}_{2} \mathrm{Cl}_{2}\right)$ : 139.2, 123.5, 122.0, 50.1, 36.8, 32.5, 19.9, 13.6.

\section{1-Butyl-3-methylimidazolium bis[(trifluoromethane)sulfonyl]amidure [BMI][NTf $\left.{ }_{2}\right]$}

A solution of $\operatorname{LiNTf}_{2}(103.0 \mathrm{~g}, 0.36 \mathrm{~mol})$ in $100 \mathrm{~mL}$ of distilled water is added dropwise to a solution of [BMI][Cl] $(60.80 \mathrm{~g}, 0.36 \mathrm{~mol})$ in $100 \mathrm{~mL}$ of water. After $2 \mathrm{~h}$ of stirring the biphasic solution, the lower phase is decanted and dissolved in $50 \mathrm{~mL}$ of $\mathrm{CH}_{2} \mathrm{Cl}_{2}$ and washed with water until an aqueous aliquot did not react anymore with silver nitrate. The ionic liquid is then filtered over alumina and celite and then dried under vacuum at $50^{\circ} \mathrm{C}$ to obtain $111.09 \mathrm{~g}$ of product (76\% yield).

NMR ${ }^{1} \mathrm{H}\left(\mathrm{CD}_{2} \mathrm{Cl}_{2}\right): 8.6(1 \mathrm{H}, \mathrm{s}), 7.3(2 \mathrm{H}, \mathrm{d}), 4.1(2 \mathrm{H}, \mathrm{t})$, $3.9(3 \mathrm{H}, \mathrm{s}), 1.8(2 \mathrm{H}, \mathrm{qt}), 1.3(2 \mathrm{H}, \mathrm{st}), 0.9(3 \mathrm{H}, \mathrm{t})$.

NMR ${ }^{13} \mathrm{C}\left(\mathrm{CD}_{2} \mathrm{Cl}_{2}\right): 135.9,130.0\left(\mathrm{CF}_{3}, \mathrm{~J}_{\mathrm{C}-\mathrm{F}}=300 \mathrm{~Hz}\right)$, 124.0, $123.3\left(\mathrm{CF}_{3}\right), 122.7,116.9\left(\mathrm{CF}_{3}\right), 110.2\left(\mathrm{CF}_{3}\right), 50.1$, 36.4, 32.1, 19.5, 13.2 .

Water content after drying: $<10 \mathrm{ppm}$. Chloride content $<3 \mathrm{mmol} \mathrm{Cl} / \mathrm{L}$.

\section{1-Butyl-3-methylimidazolium hexafluoroantimonate [BMI] $\left[\mathrm{SbF}_{6}\right]$}

Acetone $(150 \mathrm{~mL})$ is added to [BMI][Cl] $(68.0 \mathrm{~g}, 0.39 \mathrm{~mol})$ and $\mathrm{NaSbF}_{6}(100.0 \mathrm{~g}, 0.39 \mathrm{~mol})$ under an argon atmosphere. The white solution is stirred for $24 \mathrm{~h}$, then filtrated on celite. The solvent is removed under vacuum, and the ionic liquid dissolved in $40 \mathrm{~mL}$ of $\mathrm{CH}_{2} \mathrm{Cl}_{2}$, washed with distilled water until the aqueous aliquot did not react anymore with silver nitrate. The ionic liquid is dried under vacuum at $50^{\circ} \mathrm{C}$ to give $115.65 \mathrm{~g}$ of product ( $80 \%$ yield).

NMR ${ }^{1} \mathrm{H}\left(\mathrm{CD}_{2} \mathrm{Cl}_{2}\right): 8.3(1 \mathrm{H}, \mathrm{s}), 7.3(2 \mathrm{H}, \mathrm{d}), 4.1(2 \mathrm{H}, \mathrm{t})$, $3.9(3 \mathrm{H}, \mathrm{s}), 1.8(2 \mathrm{H}, \mathrm{qt}), 1.3(2 \mathrm{H}, \mathrm{qt}), 0.9(3 \mathrm{H}, \mathrm{t})$.

NMR ${ }^{13} \mathrm{C}\left(\mathrm{CD}_{2} \mathrm{Cl}_{2}\right)$ : 135.4, 123.9, 122.6, 50.2, 36.4, 31.9, 19.5, 13.2.

NMR ${ }^{1} \mathrm{H}\left(\mathrm{CD}_{2} \mathrm{Cl}_{2}\right.$, capillary tube): $8.0(1 \mathrm{H}, \mathrm{s}), 7.0(2 \mathrm{H}, \mathrm{d})$, $3.8(2 \mathrm{H}, \mathrm{t}), 3.5(3 \mathrm{H}, \mathrm{s}), 1.5(2 \mathrm{H}, \mathrm{qt}), 1.0(2 \mathrm{H}, \mathrm{st}), 0.5(3 \mathrm{H}, \mathrm{t})$. Water content after drying: < $10 \mathrm{ppm}$. 


\section{1-Butyl-3-methylimidazolium hexafluorophosphate $[\mathrm{BMI}]\left[\mathrm{PF}_{6}\right]$}

The ionic liquid is prepared as described before with [BMI][Cl] $(25.0 \mathrm{~g}, 0.143 \mathrm{~mol})$ and $\mathrm{NaPF}_{6}(24.01 \mathrm{~g}, 0.143$ $\mathrm{mol}$ ) in $150 \mathrm{~mL}$ of acetone. The uncoloured ionic liquid is recovered in good yield ( $29 \mathrm{~g}, 70 \%$ yield).

NMR ${ }^{1} \mathrm{H}\left(\mathrm{CD}_{2} \mathrm{Cl}_{2}\right): 8.4(1 \mathrm{H}, \mathrm{s}), 7.3(2 \mathrm{H}, \mathrm{d}), 4.1(2 \mathrm{H}, \mathrm{t})$, $3.9(3 \mathrm{H}, \mathrm{s}), 1.8(2 \mathrm{H}, \mathrm{qt}), 1.3(2 \mathrm{H}, \mathrm{qt}), 0.9(3 \mathrm{H}, \mathrm{t})$.

NMR ${ }^{13} \mathrm{C}\left(\mathrm{CD}_{2} \mathrm{Cl}_{2}\right): 136.0,124.1,122.7,50.3,36.6,32.2$, 19.7, 13.4.

Water content after drying: $<10 \mathrm{ppm}$. Chloride content $<3 \mathrm{mmol} \mathrm{Cl} / \mathrm{L}$.

\section{1-Butyl-3-methylimidazolium trifluoromethanesulfonate [BMI][OTf]}

A solution of $\mathrm{CH}_{3} \mathrm{SO}_{3} \mathrm{CF}_{3}(10.0 \mathrm{~g}, 0.06 \mathrm{~mol})$ in $15 \mathrm{~mL}$ of 1,1,1-trichloroethane is added dropwise to a solution of butylimidazole $(8 \mathrm{~mL}, 0.06 \mathrm{~mol})$ in $15 \mathrm{~mL}$ of trichloroethane at $-20^{\circ} \mathrm{C}$. After the addition, the temperature was allowed to warm to room temperature. The ionic phase is separated by decantation, washed twice with trichloroethane and dried at $50^{\circ} \mathrm{C}$ under vacuum to afford the ionic liquid $(16.35 \mathrm{~g}$, $95 \%$ yield).

NMR ${ }^{1} \mathrm{H}\left(\mathrm{CD}_{2} \mathrm{Cl}_{2}\right): 8.9(1 \mathrm{H}, \mathrm{s}), 7.4(2 \mathrm{H}, \mathrm{d}), 4.1(2 \mathrm{H}, \mathrm{t})$, $3.9(3 \mathrm{H}, \mathrm{s}), 1.8(2 \mathrm{H}, \mathrm{qt}), 1.3(2 \mathrm{H}, \mathrm{st}), 0.9(3 \mathrm{H}, \mathrm{t})$.

NMR ${ }^{13} \mathrm{C}\left(\mathrm{CD}_{2} \mathrm{Cl}_{2}\right): 136.9,124.1,123.4\left(\mathrm{q}, \mathrm{J}_{\mathrm{C}-\mathrm{F}}=320 \mathrm{~Hz}\right)$, 122.7, 50.2, 36.6, 32.3, 19.7, 13.4 .

Water content after drying: $25 \mathrm{ppm}$.

\section{1-Butyl-3-methylimidazolium tetrafluoroborate $\left[\mathrm{BMI}^{2}\left[\mathrm{BF}_{4}\right]\right.$}

[BMI][Cl] (120.20 g, $0.688 \mathrm{~mol})$ and $\mathrm{NaBF}_{4}(93.40 \mathrm{~g}, 0.85$ mol) are dissolved in $600 \mathrm{~mL}$ acetone under argon. The reaction medium is vigorously stirred for 4 days. The white suspension is then filtered under inert atmosphere on a plug of celite/alumina to remove $\mathrm{NaCl}$. The filtrate is reduced under vacuum and the obtained ionic liquid is redissolved in $150 \mathrm{~mL}$ of water. The ionic liquid is extracted three times with $150 \mathrm{~mL}$ of methylene chloride. The three fractions are gathered and reduced under vacuum. The colourless ionic liquid is dried under vacuum at $50^{\circ} \mathrm{C}$ for $3 \mathrm{~h}(100.5 \mathrm{~g}, 65 \%$ yield).

NMR ${ }^{1} \mathrm{H}\left(\mathrm{CD}_{2} \mathrm{Cl}_{2}\right): 8.72(1 \mathrm{H}, \mathrm{s}), 7.4(2 \mathrm{H}, \mathrm{d}), 4.2(2 \mathrm{H}, \mathrm{t})$, $3.9(3 \mathrm{H}, \mathrm{s}), 1.8(2 \mathrm{H}, \mathrm{qt}), 1.3(2 \mathrm{H}, \mathrm{st}), 0.9(3 \mathrm{H}, \mathrm{t})$.

NMR ${ }^{13} \mathrm{C}\left(\mathrm{CD}_{2} \mathrm{Cl}_{2}\right): 136.5,124.1,122.7,50.2,36.5,32.3$, $19.7,13.5$.

\section{1-Butyl-3-methylimidazolium tetra (3,5-bis(trifluromethane)phenyl)borate [BMI][BAr $]$}

$\operatorname{NaBAr}_{\mathrm{F}}(1.0 \mathrm{~g}, 1.1 \mathrm{mmol})$ and $[\mathrm{BMI}][\mathrm{Cl}](0.197 \mathrm{~g}, 1.1$ $\mathrm{mmol}$ ) are put in solution in $2 \mathrm{~mL}$ of acetone under argon. The solution is stirred during $24 \mathrm{~h}$ and then the solvent is evaporated. The orange solid is dissolved in ether and washed with water. The solvent is removed under vacuum affording $0.8 \mathrm{~g}$ ( $75 \%$ yield) of an orange solid.

NMR ${ }^{1} \mathrm{H}\left(\mathrm{CD}_{3} \mathrm{COCD}_{3}\right): 9.1(1 \mathrm{H}, \mathrm{s}), 7.7(10 \mathrm{H}, \mathrm{m}), 7.6$ $(4 \mathrm{H}, \mathrm{s}), 4.3(2 \mathrm{H}, \mathrm{t}), 4.1(3 \mathrm{H}, \mathrm{s}), 1.9(2 \mathrm{H}, \mathrm{qt}), 1.3(2 \mathrm{H}, \mathrm{st}), 0.9$ $(3 \mathrm{H}, \mathrm{t}) . \mathrm{Mp}=109^{\circ} \mathrm{C}$.

\section{1-Butyl-1-methylpyrrolidinium chloride [BMPyrro][Cl]}

$\mathrm{N}$-methylpyrrolidine $(55 \mathrm{~mL}, 0.52 \mathrm{~mol})$ and chlorobutane $(70$ $\mathrm{mL}, 0.67 \mathrm{~mol}$ ) are dissolved in $150 \mathrm{~mL}$ of acetonitrile. The reaction medium is heated and stirred under reflux for 3 days, then the solvent is removed under vacuum. The yellow oil is crystallized in $\mathrm{CH}_{3} \mathrm{CN} / \mathrm{CH}_{3} \mathrm{COOEt}$ to afford white needles (76.37 g, 80\% yield).

NMR ${ }^{1} \mathrm{H}\left(\mathrm{CD}_{2} \mathrm{Cl}_{2}\right): 3.7(4 \mathrm{H}, \mathrm{m}), 3.5(2 \mathrm{H}, \mathrm{m}), 3.1(3 \mathrm{H}, \mathrm{s})$, $2.1(4 \mathrm{H}, \mathrm{m}), 1.6(2 \mathrm{H}, \mathrm{qt}), 1.3(2 \mathrm{H}, \mathrm{st}), 0.9(3 \mathrm{H}, \mathrm{t})$.

\section{1-Butyl-1-methylpyrrolidinium bis[(trifluoromethane)sulfonyl]amidure [BMPyrro] $\left[\mathrm{NTf}_{2}\right]$}

As described for the synthesis of [BMI][NTf $\left.{ }_{2}\right]$, [BMPyrro] $\left[\mathrm{NTf}_{2}\right]$ was prepared by reaction of [BMPyrro][Cl] $(11.09 \mathrm{~g}$, $62 \mathrm{mmol})$ with $\operatorname{LiNTf}_{2}(17.78 \mathrm{~g}, 62 \mathrm{mmol})$ in water. A clear ionic liquid is recovered in good yield $(22 \mathrm{~g}, 85 \%)$.

NMR ${ }^{1} \mathrm{H}\left(\mathrm{CD}_{2} \mathrm{Cl}_{2}\right): 3.4(4 \mathrm{H}, \mathrm{m}), 3.2(2 \mathrm{H}, \mathrm{m}), 3.0(3 \mathrm{H}, \mathrm{s})$, $2.2(4 \mathrm{H}, \mathrm{m}), 1.7(2 \mathrm{H}, \mathrm{qt}), 1.3(2 \mathrm{H}, \mathrm{st}), 0.9(3 \mathrm{H}, \mathrm{t})$.

NMR ${ }^{13} \mathrm{C}\left(\mathrm{CD}_{2} \mathrm{Cl}_{2}\right): 129.7\left(\mathrm{CF}_{3}\right), 123.4\left(\mathrm{CF}_{3}\right), 117.0$ $\left(\mathrm{CF}_{3}\right), 110.6\left(\mathrm{CF}_{3}\right), 64.8,48.6,25.8,21.7,19.7,13.4$.

Water content after drying: $<10 \mathrm{ppm}$.

\subsection{Ligands Synthesis}

\section{Acenaphtyl-bis(4-trifluoromethylphenylimine): L1}

Acenaphtenequinone (14.57 g, $0.08 \mathrm{~mol})$, camphorsulphonic acid $(0.36 \mathrm{~g})$ and 4-trifluoromethylaniline $(20 \mathrm{~mL}, 0.16 \mathrm{~mol})$ were dissolved in $26 \mathrm{~mL}$ of dry toluene. The solution is refluxed for 5 days. The water formed during the reaction is separated in a Dean-Stark trap. Removing the volatiles from the red solution under vacuum afforded an orange solid which is crystallized in $\mathrm{CHCl}_{3} / \mathrm{C}_{5} \mathrm{H}_{12}$. Crystals are washed with $\mathrm{C}_{5} \mathrm{H}_{12}$ (25.90 g, $70 \%$ yield).

NMR ${ }^{1} \mathrm{H}\left(\mathrm{CDCl}_{3}\right): 7.9(2 \mathrm{H}, \mathrm{d}), 7.7(4 \mathrm{H}, \mathrm{d}), 7.4(2 \mathrm{H}, \mathrm{t}), 7.2$ $(4 \mathrm{H}, \mathrm{d}), 6.8(2 \mathrm{H}, \mathrm{d})$. 


\section{Diacetyl-bis(2,6-diisopropylphenylimine): L2}

Butanedione $(18.6 \mathrm{~mL}, 0.21 \mathrm{~mol})$ is slowly added to a solution of 2,6-diisopropylaniline $(80 \mathrm{~mL}, 0.42 \mathrm{~mol})$ and formic acid $(24 \mathrm{~mL})$ in $200 \mathrm{~mL}$ of methanol. After $30 \mathrm{~min}$ of stirring, the yellow precipitate is filtrated and washed with cold methanol. The solid is then dissolved in $160 \mathrm{~mL}$ of pentane, dried over $\mathrm{MgSO}_{4}$, concentrated under vacuum, and crystallized in methanol to afford yellow needles $(55.65 \mathrm{~g}, 65 \%$ yield).

NMR ${ }^{1} \mathrm{H}\left(\mathrm{CD}_{2} \mathrm{Cl}_{2}\right): 7.1(6 \mathrm{H}, \mathrm{m}), 2.7(4 \mathrm{H}, \mathrm{ht}), 2.1(6 \mathrm{H}, \mathrm{s})$, $1.2(24 \mathrm{H}, \mathrm{dd})$.

NMR ${ }^{13} \mathrm{C}\left(\mathrm{CD}_{2} \mathrm{Cl}_{2}\right): 168.5,145.0,135.5,124.1,123.4$, 28.8, 23.1, 22.8, 16.6.

\section{Glyoxal bis(4-methylphenylimine): L3}

Glyoxal ( $40 \%$ in water, $9 \mathrm{~mL}, 0.1 \mathrm{~mol})$ is added dropwise to a solution of $p$-toluidine $(21.50 \mathrm{~g}, 0.2 \mathrm{~mol})$ in $100 \mathrm{~mL}$ of isopropyl alcohol at $0^{\circ} \mathrm{C}$. After $3 \mathrm{~h}$ of stirring, the yellow precipitate is filtered and recrystallized in isopropylalcohol yielding yellow needles $(6.58 \mathrm{~g}, 28 \%)$.

NMR ${ }^{1} \mathrm{H}\left(\mathrm{CDCl}_{3}\right): 8.4(2 \mathrm{H}, \mathrm{s}), 7.2(8 \mathrm{H}, \mathrm{s}), 2.3(6 \mathrm{H}, \mathrm{s})$.

\section{Glyoxal bis(2,6-dimethylphenylimine): L4}

Glyoxal ( $40 \%$ in water, $5 \mathrm{~mL}, 0.056 \mathrm{~mol}$ ) is added dropwise to a solution of 2,6-dimethylphenylaniline ( $13 \mathrm{~mL}, 0.11 \mathrm{~mol})$ and formic acid $(5 \mathrm{~mL})$ in $25 \mathrm{~mL}$ of methanol. After $2 \mathrm{~h}$ of stirring, the orange precipitate is filtered and washed with methanol, recrystallized in cold methanol yielding a first crop of yellow needles $(2.7 \mathrm{~g})$. A second crop was obtained with a recrystallization in an ethanol/hexane mixture $(0.7 \mathrm{~g}$, total yield $=23 \%$ ).

$\operatorname{NMR}{ }^{1} \mathrm{H}\left(\mathrm{C}_{6} \mathrm{D}_{6}\right): 7.9(2 \mathrm{H}, \mathrm{s}), 6.9(6 \mathrm{H}, \mathrm{m}), 2.0(12 \mathrm{H}, \mathrm{s})$.

\section{2-(4-methoxyphenylaldimino)pyridine: L5}

A solution of 2-carboxaldehydepyridine ( $3 \mathrm{~mL}, 0.031 \mathrm{~mol})$ is added to $p$-anisidine $(3.81 \mathrm{~g}, 0.031 \mathrm{~mol})$ and two drops of formic acid in $20 \mathrm{~mL}$ of methanol. The black solution is stirred for $3 \mathrm{~h}$ and concentrated under vacuum. The black oil is then distilled under reduce pressure $\left(10^{-2} \mathrm{mbar}, 50^{\circ} \mathrm{C}\right)$. The yellow/brown oil obtained spontaneously crystallizes. The solid is then washed with heptane to yield brown crystals (4 g, 60\% yield).

NMR ${ }^{1} \mathrm{H}\left(\mathrm{CD}_{2} \mathrm{Cl}_{2}\right): 8.6(2 \mathrm{H}, \mathrm{d}), 8.2(1 \mathrm{H}, \mathrm{d}), 7.8(1 \mathrm{H}, \mathrm{t})$, $7.3(3 \mathrm{H}, \mathrm{m}), 6.9(2 \mathrm{H}, \mathrm{d}), 3.7(3 \mathrm{H}, \mathrm{s})$.

NMR ${ }^{13} \mathrm{C}\left(\mathrm{CD}_{2} \mathrm{Cl}_{2}\right)$ : 159.3, 158.8, 155, 150, 144, 137 , $125,123,121,144,56$.

\section{2,6-bis(2,6-dimethylphenylimino)pyridine: L6}

To a solution of 2,6-diacetylpyridine $(1.0 \mathrm{~g}, 0.0061 \mathrm{~mol})$ in $20 \mathrm{~mL}$ of methylene chloride, is added $o$-toluidine $(3 \mathrm{~mL}$, $0.028 \mathrm{~mol}$ ) and two drops of formic acid. The solution is stirred for $12 \mathrm{~h}$ under argon and concentrated under vacuum. The brown oil is cooled to $-30^{\circ} \mathrm{C}$ and washed with methanol to recover a yellow solid $(1.2 \mathrm{~g}, 60 \%$ yield $)$.

NMR ${ }^{1} \mathrm{H}\left(\mathrm{CD}_{2} \mathrm{Cl}_{2}\right): 8.4(2 \mathrm{H}, \mathrm{d}), 7.9(1 \mathrm{H}, \mathrm{t}), 7(6 \mathrm{H}, \mathrm{m}), 6.6$ $(2 \mathrm{H}, \mathrm{d}), 2.3(6 \mathrm{H}, \mathrm{s}), 2.1(6 \mathrm{H}, \mathrm{s})$.

Complexes 1-6 were synthesized as previously described [15].

\section{RESULTS AND DISCUSSION}

The benefits of using ionic liquids in catalysis may be numerous. Their large liquid range and their poor volatility were among the driving force of their first development. Due to their unique set of physico-chemical properties (solvation, polarity, structure...), ionic liquids proved to be an effective means for immobilization of catalysts and product separation. They offer new opportunities of developments of new biphasic (multiphasic) catalytic processes. The ionic liquids are based on many different combinations of organic cations and inorganic or organic anions. The first generation of ionic liquids are based on chloroaluminate anions. These ionic liquids can be Lewis basic or Lewis acidic according to the molar ratio of $\mathrm{AlCl}_{3}$ and dialkylimidazolium chloride. The acidic chloroaluminates have been successfully used for the oligomerization of propylene and butene catalyzed by the cationic $\mathrm{Ni}(\mathrm{II})$ organometallic complexes. The acidic alkylchloroaluminates play the dual role of metal activator (co-catalyst) and catalyst solvent. The second generation of ionic liquids that we have used in this study are based on non-chloroaluminate anions, such as $\mathrm{PF}_{6}^{-}, \mathrm{BF}_{4}^{-}, \mathrm{CF}_{3} \mathrm{SO}_{3}^{-}$, $\mathrm{N}\left(\mathrm{CF}_{3} \mathrm{SO}_{2}\right)_{2}^{-}$(named $\left.\mathrm{NTf}_{2}\right), \mathrm{SbF}_{6}^{-}$(Fig. 1). These ionic liquids are used as solvents to immobilize the nickel active catalysts that can be generated either by activation of a $\mathrm{Ni}$ (II) salt with different alkylaluminium derivatives or by oxidative addition of a Brönsted acid on a $\mathrm{Ni}(0)$ precursor. Here are reported the successful attempts to oligomerize ethylene with both generations of ionic liquids with nickel complexes.

\subsection{Ethylene Oligomerization in Chloroaluminate lonic Liquids}

We have performed a first series of biphasic experiments with $\mathrm{Ni}$ (II) dichloride complexes 1-2 and 3 (Fig. 2), using chloroaluminate ionic liquids as solvents, based on the mixture of 1-butyl-3-methylimidazolium chloride [BMI][Cl] and $\mathrm{AlCl}_{3}$ (Table 1). The reaction products separate as a second clear organic upper layer. The catalyst phase can be recycled 


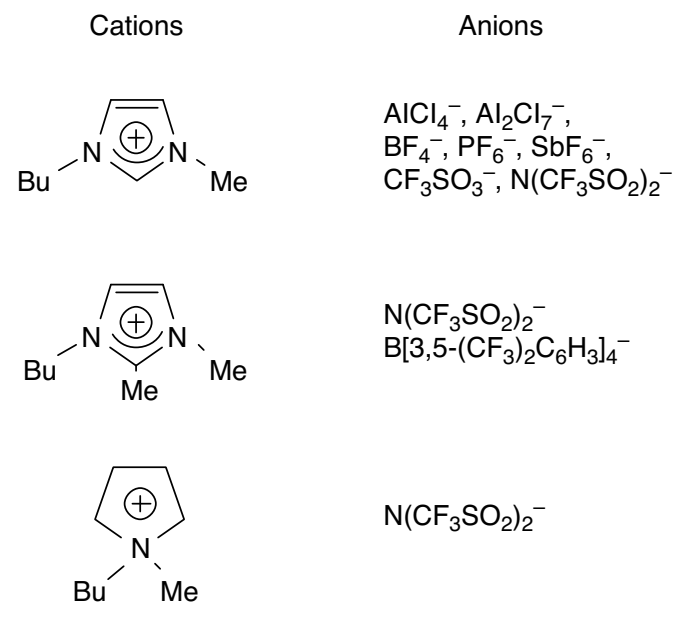

Figure 1

Different ionic liquids used in this study.

and reuse after separation of the products. For comparison, homogeneous experiments have been carried out without ionic liquids, using organic solvents such as toluene or chlorobenzene (Entries 1-4).

In one homogeneous phase, using toluene as the solvent, 1 complex activated with MAO, leads mainly to the formation of $\alpha$-olefins with a Schulz-Flory distribution (Entry 1). In a more polar solvent, such as chlorobenzene, butenes and hexenes are mainly obtained but with lower $\alpha$-olefin selectivity (Table 2, Entry 2). We can assume that in polar solvents dissociation of cationic active Ni-complex ion pairs is made easier which may favour chain transfer reactions and isomerization. Entry 3 and 4 underline the importance of the nature of the ligand. With pyridine (Entry 3), 2-butene is formed as the major product. This is also the case when $\mathrm{Ni}(\mathrm{II})$ salt is used in the absence of ligand. It seems that the pyridine ligand is no more present in the coordination sphere of the metal. As expected, a bulky ligand such as in $\mathbf{2}$ complex leads to the formation of polyethylene by rending the termination reactions more difficult. All the Ni-complexes described before were found to be much more active in the presence of chloroaluminate ionic liquids. The ionic liquid effect could be ascribed to an increase of the electrophilic nature of the nickel catalyst resulting from the weak coordinating ability of chloroaluminate anions. In chloroaluminate as in toluene, the catalyst structure has a substantial effect on the product chain length distribution. Nevertheless, in acidic ionic liquid (ionic liquid B, Entry 6), 1 complex shows the same low selectivity for $\alpha$-olefins than $\mathbf{3}$ complex (Entry 5 ). This result seems to indicate that in this acidic medium, the ligand prefers to coordinate to the Lewis acidic aluminium centre than on nickel. In order to prevent the decoordination of the ligand, neutral chloroaluminate ionic liquid (ionic liquid $\mathrm{A}$ : [BMI][Cl] $/ \mathrm{AlCl}_{3}: 1 / 1$ molar ratio) was used in the next experiments and the activator MAO was chosen to obtain a narrower distribution of olefins. Entry 8 clearly indicates that the $\mathbf{1}$ complex is more active in the chloroaluminate than in toluene, the products are mainly butenes but partly isomerized, branched hexenes and internal linear hexenes are obtained in good quantities (Table 2). It should be noticed that isomerization is lower than in the presence of pyridine ligand (Entry 5) or in acidic medium (Entry 6). As in organic solvent, sterically encumbered substitution patterns (Entry 9, complex 2) reduce the chain transfer rate affording polyethylene. In that case, the product distribution is bimodal, indicating that two active species are probably formed. While in homogeneous runs (Entries 1-2, Table 2), mainly linear 1hexene is obtained, in chloroaluminate ionic liquids (Entries 6-8), branched hexenes are mainly obtained. These branched hexenes result from consecutive reactions of butenes as described in Figure 3.<smiles>FC(F)(F)c1ccc(N2C3=C(c4cccc5cccc2c45)N(c2ccc(C(F)(F)F)cc2)[N+]3(Cl)Cl)cc1</smiles>

1<smiles></smiles>

4

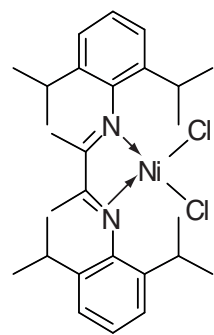

2

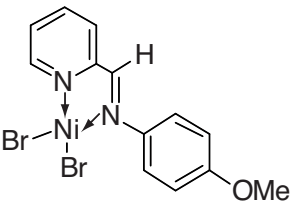

5<smiles></smiles>

3

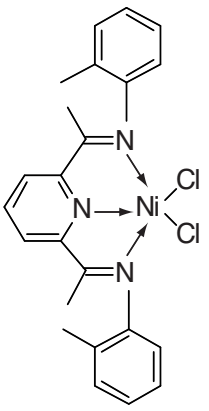

6

Figure 2

Ni complexes used in catalytic experiments. 
TABLE 1

Oligomerization of ethylene in organic solvents and in chloroaluminate ionic liquids

\begin{tabular}{|c|c|c|c|c|c|c|c|c|c|}
\hline \multirow{2}{*}{ Entry } & \multirow{2}{*}{$\mathrm{Ni}$} & \multirow{2}{*}{ Solvent } & \multirow{2}{*}{ Activator } & \multirow{2}{*}{$\mathrm{TOF}^{\mathrm{a}}$} & \multicolumn{4}{|c|}{ Product distribution (wt $\%$ ) } & \multirow{2}{*}{$\begin{array}{c}\alpha \text {-olefin } \\
(\mathrm{wt} \% \text { ) }\end{array}$} \\
\hline & & & & & $\mathrm{C} 4$ & $\mathrm{C} 6$ & $\mathrm{C} 8$ & $\mathrm{C} 10$ & \\
\hline 1 & 1 & Toluene & MAO & 17000 & 27 & 23 & 17 & 12 & 80 \\
\hline 2 & 1 & chlorobenzene & MAO & 23000 & 56 & 31 & 8 & 5 & 66 \\
\hline 3 & 3 & Toluene & MAO & 2500 & 97 & 3 & 0 & 0 & 30 \\
\hline 4 & 2 & Toluene & MAO & 18000 & \multicolumn{4}{|c|}{ polyethylene (PE) } & 0 \\
\hline 5 & $3^{\mathbf{c}}$ & ionic liquid $\mathrm{A}^{\mathrm{d}}$ & MAO & 68000 & 66 & 31 & 3 & 0 & 27 \\
\hline 6 & $1^{g}$ & ionic liquid $\mathrm{B}^{\mathrm{e}}$ & EADC $^{\mathrm{f}}$ & 14000 & 59 & 31 & 8 & 2 & 27 \\
\hline 7 & $1^{\mathrm{c}}$ & ionic liquid $\mathrm{A}$ & MAO & 41000 & 64 & 30 & 4 & 1 & 41 \\
\hline 8 & 1 & ionic liquid A & MAO & 78000 & 73 & 22 & 3 & 1 & 44 \\
\hline 9 & $2^{\mathrm{c}}$ & ionic liquid $\mathrm{A}$ & MAO & 25000 & \multicolumn{4}{|c|}{$\begin{array}{c}\mathrm{PE}: 57 \\
\mathrm{C} 4: 41 \\
\mathrm{C} 6: 2\end{array}$} & 26 \\
\hline
\end{tabular}

Reaction conditions: $P=25$ bars, $T=40^{\circ} \mathrm{C}$, time $=30 \mathrm{~min}, \mathrm{Ni}: 0.01 \mathrm{mmol}, \mathrm{Al} / \mathrm{Ni}=200$. Entries [1-4]: $50 \mathrm{~mL}$ of organic solvent. Entries [5-9]: $5 \mathrm{~mL}$ of ionic liquid.

a TOF: $\mathrm{g}$ of ethylene consumed/g Ni.h.

${ }^{\mathrm{b}} \mathrm{Wt} \%$ of 1-butene in $\mathrm{C} 4$ fraction, remainder is 2-butene.

${ }^{\mathrm{c}} \mathrm{Ni}: 0.02 \mathrm{mmol}$.

${ }^{\mathrm{d}}$ Ionic liquid A: [BMI][Cl] $(5.58 \mathrm{~g}), \mathrm{AlCl}_{3}(4.27 \mathrm{~g}),[\mathrm{BMI}][\mathrm{Cl}] / \mathrm{AlCl}_{3}$ molar ratio $=1$

${ }^{\mathrm{e}}$ Ionic liquid B: BMIC/AlCl $3 / \mathrm{EADC}$ : 1/1.22/0.11 molar ratio.

${ }^{f}$ EADC: ethylaluminium dichloride added with the ionic liquid B.

g Ni: $0.1 \mathrm{mmol}$.

TABLE 2

Distribution (wt \%) of the C6 isomers obtained in Table 1

\begin{tabular}{|c|c|c|c|c|c|c|c|c|}
\hline Entry & & & & & & & Total Linear & Total Branched \\
\hline 1 & 1 & 81 & 1 & 1 & 16 & 0 & 98 & 2 \\
\hline 2 & 0 & 69 & 0 & 0 & 31 & 0 & 100 & 0 \\
\hline 5 & 3 & 4 & 7 & 9 & 30 & 46 & 43 & 56 \\
\hline 6 & 4 & 4 & 6 & 12 & 32 & 42 & 48 & 52 \\
\hline 7 & 4 & 6 & 9 & 16 & 35 & 29 & 57 & 42 \\
\hline 8 & 4 & 7 & 8 & 12 & 32 & 38 & 51 & 50 \\
\hline
\end{tabular}

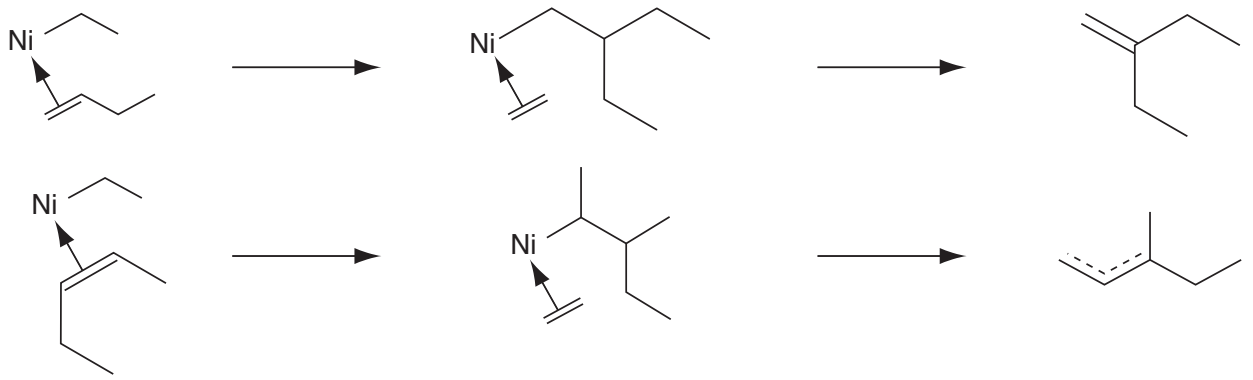

Figure 3

Consecutive reaction responsible for the formation of hexenes. 


\subsection{Ethylene Oligomerization in Non-chloroaluminate ionic liquids}

\subsubsection{Activation of $\mathrm{Ni}(I I)$ with $\mathrm{MAO}$}

Chloroaluminates are promising solvents for the oligomerization of ethylene in terms of activities and catalyst separation and recycling but they still promote the isomerization of the double bond giving internal olefin as main products. It is the reason why we realized a second series of experiments in which non-chloroaluminates where used as catalyst solvents.

At first, nickel precursors were activated using different alkylaluminium. The effects of each constituents of the catalytic system were analyzed, namely the nature of the ionic liquid (effect of cations and anions), the nature of the activator, the effect of the addition of a stabilizer (a Lewis base), and the nature of the nitrogen ligand.

As seen in Table 3, with non-chloroaluminate ionic liquids and MAO as the activator of the $\mathbf{1}$ complex, the first results obtained were disappointing. At the end of the catalytic run, the reaction medium is black, suggesting that nickel was reduced to colloidal $\mathrm{Ni}(0)$. The hexafluophosphate ionic liquid (Table 3, Entry 3) immediately reacts with the alkylaluminium (MAO) yielding a white precipitate and an exothermic reaction. This white precipitate has not been identified but one can assume that some exchanges occur between fluoride and methyl groups [of MAO]. As the dialkylimidazolium cations may lead to the formation of coordinative imidazolylidene carbene, 1-butyl-2,3-dimethyl-imidazolium and $\mathrm{N}, \mathrm{N}$ '-butylmethylpyrrolidinium cation was used. Although yields of reaction are very poor compared to homogeneous systems, the best results were obtained with the pyrrolidinium cation associated with the $\mathrm{NTf}_{2}$ anion. To explain the inhibiting effect of the ionic liquids, stoichiometric amount of
TABLE 3

Effect of ionic liquids on the oligomerization of ethylene with $\mathrm{Ni}(\mathrm{II}) / \mathrm{MAO}$ systems

\begin{tabular}{c|c|c|c|c|c}
\hline Entry & Ionic liquid & $\begin{array}{c}\text { Activity TOF } \\
\left(\mathrm{g} \mathrm{C}_{2}=/ \mathrm{g} \text { Ni.h }\right)\end{array}$ & \multicolumn{2}{|c|}{$\begin{array}{c}\text { Product distribution } \\
(\mathrm{wt} \%)\end{array}$} & $\begin{array}{c}\alpha \text {-olefin } \\
(\mathrm{wt} \%)\end{array}$ \\
\hline 1 & {$[\mathrm{BMI}]\left[\mathrm{NTf}_{2}\right]$} & 70 & 99 & 1 & 26 \\
\hline 2 & {$[\mathrm{BMI}]\left[\mathrm{SbF}_{6}\right]$} & 25 & 99 & 1 & 70 \\
\hline 3 & {$\left[\mathrm{BMI}\left[\left[\mathrm{PF}_{6}\right]\right.\right.$} & 0 & - & - & - \\
\hline 4 & {$[\mathrm{BMMI}]\left[\mathrm{NTf}_{2}\right]$} & 0 & - & - & - \\
\hline 5 & {$[\mathrm{BMI}]\left[\mathrm{BF}_{4}\right]$} & 0 & - & - & - \\
\hline 6 & {$[\mathrm{BMPyrro}]\left[\mathrm{NTf}_{2}\right]$} & 100 & 70 & 30 & 70 \\
\hline 7 & {$[\mathrm{BMI}][\mathrm{OTf}]$} & 0 & - & - & - \\
\hline
\end{tabular}

Reaction conditions: 1 complex $(0.01 \mathrm{mmol})$, toluene $(10 \mathrm{~mL}), 5 \mathrm{~mL}$ of ionic liquid, $\mathrm{Al} / \mathrm{Ni}=200$ molar, $T=40^{\circ} \mathrm{C}, t=40 \mathrm{~min}$.

${ }^{\text {a }} \mathrm{Wt} \%$ of 1-butene in $\mathrm{C} 4$ fraction, remainder is 2-butene

$[\mathrm{BMI}]\left[\mathrm{NTf}_{2}\right]$ were added in toluene solution of $\mathbf{1}$. The results are summarized in Table 4.

When only one equivalent of [BMI] $\left[\mathrm{NTf}_{2}\right]$ relative to $\mathbf{1}$ is added, activity drops down significantly. With addition of 10 equivalents, the system is nearly inactive which demonstrates the poisoning effect of the ionic liquid on the $\mathrm{Ni}$ catalyst (Fig. 4). However, by using 10 equivalents of a very weakly coordinating $\mathrm{BAr}_{\mathrm{F}}$ anion, the activity is less decreased. It can be assumed that the interaction of the $\mathrm{BAr}_{\mathrm{F}}$ anion with the cationic nickel or with the aluminium center of the activator is weaker than with the $\mathrm{N}\left(\mathrm{CF}_{3} \mathrm{SO}_{2}\right)_{2}$ anion. It has indeed been recently shown that in the absence of ligand, $\mathrm{NTf}_{2}$ anion can behave as a coordinating ligand toward metal center through a range of nitrogen and/or oxygen binding modes [16].

TABLE 4

Ethylene oligomerization with $\mathbf{1}$ complex in toluene with addition of stoichiometric amount of ionic liquids

\begin{tabular}{|c|c|c|c|c|c|c|c|c|c|}
\hline \multirow{2}{*}{ Entry } & \multirow{2}{*}{ Ionic Liquid } & \multirow{2}{*}{$\begin{array}{l}\text { Ionic Liquid / Ni } \\
\quad(\text { molar ratio })^{\mathrm{d}}\end{array}$} & \multirow{2}{*}{$\begin{array}{l}\text { Activity TOF } \\
\left(\mathrm{g} \mathrm{C}_{2}=/ \mathrm{g} \text { Ni.h) }\right.\end{array}$} & \multicolumn{4}{|c|}{$\begin{array}{l}\text { Product distribution } \\
\qquad(\mathrm{wt} \%)\end{array}$} & \multirow{2}{*}{$\begin{array}{c}\alpha \text {-olefin }{ }^{\mathrm{a}} \\
(\mathrm{wt} \%)\end{array}$} & \multirow{2}{*}{$\begin{array}{c}\alpha \\
\text { factor }^{b}\end{array}$} \\
\hline & & & & $\mathrm{C} 4$ & C6 & $\mathrm{C} 8$ & $\mathrm{C} 10$ & & \\
\hline $1^{\mathrm{c}}$ & no ionic liquid & 0 & 17000 & 27 & 23 & 17 & 12 & 80 & 0.7 \\
\hline 2 & {$[\mathrm{BMI}]\left[\mathrm{NTf}_{2}\right]$} & 1 & 12700 & 32 & 16 & 9 & 1 & 65 & 0.5 \\
\hline 3 & {$[\mathrm{BMI}]\left[\mathrm{NTf}_{2}\right]$} & 3 & 6600 & 31 & 22 & 12 & 6 & 70 & 0.5 \\
\hline 4 & {$[\mathrm{BMI}]\left[\mathrm{NTf}_{2}\right]$} & 10 & 850 & 36 & 64 & - & - & 80 & \\
\hline 5 & {$[\mathrm{BMI}]\left[\mathrm{BAr}_{\mathrm{F}}\right]^{\mathrm{e}}$} & 10 & 4500 & 20 & 15 & 11 & 6 & 95 & 0.5 \\
\hline
\end{tabular}

Reaction conditions: 1 complex: $0.02 \mathrm{mmol}$, toluene: $50 \mathrm{~mL}, \mathrm{MAO}$ co-catalyst: $\mathrm{Al} / \mathrm{Ni}=200$ molar, $\mathrm{P}=25 \mathrm{bar}, \mathrm{T}=40^{\circ} \mathrm{C}, \mathrm{t}=30 \mathrm{~min}$

${ }^{\mathrm{a}} \mathrm{Wt} \%$ of 1-butene in $\mathrm{C} 4$ fraction, remainder is 2-butene.

${ }^{\mathrm{b}} \alpha=$ Schulz-Flory constant $=\mathrm{Cn}+2 / \mathrm{Cn}$

c 1 complex: 0.01 mmol.

${ }^{\mathrm{d}}$ Entries 2-5: ionic liquid is introduced into the reactor after the MAO and the nickel precursor.

${ }^{\mathrm{e}} \mathrm{BAr}_{\mathrm{F}}=\mathrm{B}\left[3,5-\left(\mathrm{CF}_{3}\right)_{2} \mathrm{C}_{6} \mathrm{H}_{3}\right]_{4}$. 


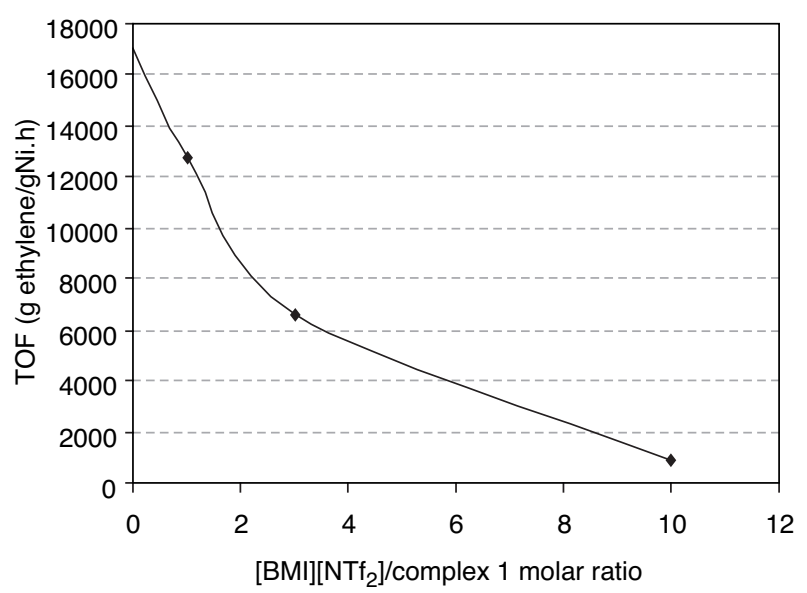

Figure 4

Poisoning effect of addition of stoichiometric amount of $[\mathrm{BMI}]\left[\mathrm{NTf}_{2}\right]$ ionic liquid.

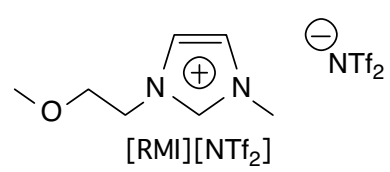

Figure 5

$[\mathrm{RMI}]\left[\mathrm{NTf}_{2}\right]$
Other alkylaluminium activators of $\mathbf{1}$ complex, such as diethylaluminium chloride (DEAC) have been used instead of MAO. No significant gain in activity could be obtained.

In order to stabilize the nickel active complex and to avoid its reduction to nickel metal, different Lewis bases were added to the catalytic system (Table 5).

In these experiments, MAO in toluene was first injected in the reactor. A suspension of the nickel complex in the ionic liquid $[\mathrm{BMI}]\left[\mathrm{NTf}_{2}\right]$ containing the stabilizer was then added. At the end of the test, all the catalytic solutions are clear. No $\mathrm{Ni}(0)$ particles are detected. The addition of THF (20 eq $/ \mathrm{Ni})$ has a significant effect on the reaction activity (Entry 1) and on the 1-butene selectivity. Moreover, a more important excess of THF (20 to $1200 \mathrm{eq} / \mathrm{Ni}$ ) seems to inhibit the active site (Fig. 5 and Table 5, Entries 1 and 2). In order to immobilize the stabilizer in the ionic phase, the ether was tagged with an imidazolium group (Table 5, Entry 4). The activity and stability of the system are enhanced in a similar way than with the addition of di-tert-butyl ether (Entry 5).

We decided to study the effect of the nature of the nitrogen imine ligand on the catalytic performances. [BMI][NTf $\left.\mathrm{NT}_{2}\right]$ was chosen as the solvent, and MAO in toluene as the $\mathrm{Ni}$ activator. Results are reported in Table 6.

The $\mathbf{2}$ and $\mathbf{4}$ complexes described in Entries 1 and 3 yield higher activities but selectivities directed towards the formation of polyethylene. The effect of bulky diimine ligands is the same in $[\mathrm{BMI}]\left[\mathrm{NTf}_{2}\right]$ and in toluene (see Table 1, Entry 4). At the end of the test, the ionic liquid phase was blue for Entry 1 (2 complex) and red for Entry 3 (4 complex). The

TABLE 5

Effect of the addition of Lewis bases on $\mathbf{1} / \mathrm{MAO}$ catalytic system in $[\mathrm{BMI}]\left[\mathrm{NTf}_{2}\right]$

\begin{tabular}{|c|c|c|c|c|c|c|c|}
\hline \multirow{2}{*}{ Entry } & \multirow{2}{*}{ Lewis Base (eq/Ni) } & \multirow{2}{*}{$\begin{array}{l}\text { Activity TOF } \\
\left(\mathrm{g} \mathrm{C}_{2}=/ \mathrm{g} \text { Ni.h }\right)\end{array}$} & \multicolumn{4}{|c|}{ Product distribution (wt $\%$ ) } & \multirow{2}{*}{$\begin{array}{c}\alpha \text {-olefin }{ }^{\mathrm{a}} \\
(\mathrm{wt} \%)\end{array}$} \\
\hline & & & $\mathrm{C} 4$ & C6 & C8 & $\mathrm{C10}$ & \\
\hline 1 & THF (20) & 600 & 95 & 5 & 0 & 0 & 85 \\
\hline 2 & THF (1200) & 140 & 95 & 5 & 0 & 0 & 80 \\
\hline 3 & L1 (20) & 20 & 99 & 1 & 0 & 0 & 75 \\
\hline 4 & {$[\mathrm{RMI}]\left[\mathrm{NTf}_{2}\right]^{\mathrm{b}}(20)$} & 300 & 92 & 5 & 2 & 1 & 42 \\
\hline 5 & $\operatorname{DBE}^{\mathrm{c}}(20)$ & 430 & 97 & 3 & 0 & 0 & 41 \\
\hline 6 & $\operatorname{ACN}^{\mathrm{d}}(20)$ & 540 & 100 & 0 & 0 & 0 & \\
\hline
\end{tabular}

Reaction conditions: 1 complex: $0.01 \mathrm{mmol}$, toluene: $10 \mathrm{~mL}$, [BMI][NTf 2 ]: $5 \mathrm{~mL}, \mathrm{MAO}$ co-catalyst: $\mathrm{Al} / \mathrm{Ni}=200 \mathrm{molar}, P=25 \mathrm{bar}, T=40^{\circ} \mathrm{C}, t=30 \mathrm{~min}$.

${ }^{\mathrm{a}} \mathrm{Wt} \%$ of 1-butene in $\mathrm{C} 4$ fraction, remainder is 2-butene.

${ }^{\mathrm{b}}$ Figure 5 .

${ }^{\mathrm{c}}$ DBE: di-tert-butylether.

d ACN: acetonitrile. 
TABLE 6

Effect of the nature of the nitrogen ligand on the Ni-catalyzed ethylene transformation in [BMI][NTf $\left.{ }_{2}\right]$

\begin{tabular}{|c|c|c|c|c|c|c|c|}
\hline \multirow{2}{*}{ Entry } & \multirow{2}{*}{ Complex } & \multirow{2}{*}{$\begin{array}{l}\text { Activity TOF } \\
\left(\mathrm{g} \mathrm{C}_{2} / \text { /g Ni.h) }\right.\end{array}$} & \multicolumn{4}{|c|}{ Product distribution (wt\%) } & \multirow{2}{*}{$\begin{array}{c}\alpha \text {-olefin }{ }^{\mathrm{a}} \\
(\mathrm{wt} \%)\end{array}$} \\
\hline & & & $\mathrm{C} 4$ & C6 & C8 & C10 & \\
\hline 1 & 2 & 800 & 5 & & polyethylene & & 70 \\
\hline 2 & 3 & 280 & 99 & 1 & 0 & 0 & 60 \\
\hline 3 & 4 & 700 & 25 & & polyethylene & & 75 \\
\hline 4 & 5 & 700 & 88 & 12 & 0 & 0 & 35 \\
\hline 5 & 6 & 2600 & 93 & 7 & 0 & 0 & 47 \\
\hline
\end{tabular}

Reaction conditions: Ni complex: $0.03 \mathrm{mmol}$, toluene: $10 \mathrm{~mL},[\mathrm{BMI}]\left[\mathrm{NTf}_{2}\right]: 5 \mathrm{~mL}, \mathrm{MAO}$ co-catalyst: $\mathrm{Al} / \mathrm{Ni}=200 \mathrm{molar}, P=25 \mathrm{bar}, T=40^{\circ} \mathrm{C}, t=30 \mathrm{~min}$.

${ }^{a} \mathrm{Wt} \%$ of 1-butene in $\mathrm{C} 4$ fraction, remainder is 2-butene.

blue colour quickly disappeared indicating the presence of an unstable species. This blue colour could be assigned to the formation of the (diimine) $\mathrm{NiMe}_{2}$ species, indicating that with sterically encumbered ligands, alkylation of nickel is effective and the alkyl complex is stable enough in solution. In order to increase the stabilization of the active center, $\mathbf{5}$ complex containing a ligand bearing a pyridine group was used (Entry 4). This ligand leads to quite a good activity, but poor selectivities towards $\alpha$-olefins are obtained. The use of bis(imino)pyridine in the $\mathbf{6}$ complex yields the most active catalyst. Butenes are mainly obtained, but 1-butene is partially isomerized into 2-butenes.

\subsubsection{Activation of $\mathrm{Ni}(0)$ with a Brönsted Acid}

In a second series of experiments, the $\mathrm{Ni}$ active catalyst was generated directly in ionic liquids by activation of $\mathrm{Ni}^{(0)}(\mathrm{COD})_{2}\left(\mathrm{COD}=1,5\right.$-cyclooctadiene) with $\mathrm{H}\left(\mathrm{Et}_{2} \mathrm{O}\right)_{2} \mathrm{BAr}_{\mathrm{F}}$ (noted $\mathrm{HBAr}_{\mathrm{F}}$ in Table 9 with $\mathrm{BAr}_{\mathrm{F}}=\mathrm{B}\left[3,5-\left(\mathrm{CF}_{3}\right)_{2} \mathrm{C}_{6} \mathrm{H}_{3}\right]_{4}$ ), with or without $\alpha$-diimine ligand and in the absence of $\mathrm{Al}$ cocatalyst (Fig. 6).

In the absence of nitrogen ligand, using first toluene as the solvent (comparative example), the reaction activity is very low (Table 9, Entry 1). The reaction activity can be enhanced by using ionic liquids. For a same $[\mathrm{BMI}]$ cation, the activity increases as follows $\mathrm{SbF}_{6}>>\mathrm{NTf}_{2}>\mathrm{PF}_{6}>>\mathrm{OTf}$. For a same $\mathrm{NTf}_{2}$ anion, the Ni activity is greater with imidazolium than with pyrrolidinium cation. The polarity and coordination properties of the ionic liquid, which are likely to be anion and cation dependent, are probably one of the main factors that affects the Ni-catalyst activity. For most active systems (Table 9, Entries 2 and 5), the nature of the ionic liquid does not seem to affect the product distribution. Butenes are obtained as the major products.

But as in chloroaluminates, the 1-butene selectivity is still low. It was also checked that the presence of the Brönsted acid was necessary to obtain an active catalyst. We were nevertheless surprised to observe that in $[\mathrm{BMI}]\left[\mathrm{NTf}_{2}\right]$, without any addition of acid, ethylene was consumed to form butenes. The proton NMR and FAB mass spectra of the ionic liquid after the catalysis showed the presence of an imidazolium cation substituted with an ethyl group on the $\mathrm{C}(2)$ carbon [17]. Its formation can be explained by an oxidative addition of the imidazolium cation on $\mathrm{Ni}(0)$, followed by the insertion of ethylene into the $\mathrm{Ni}-\mathrm{H}$ bond. A reductive

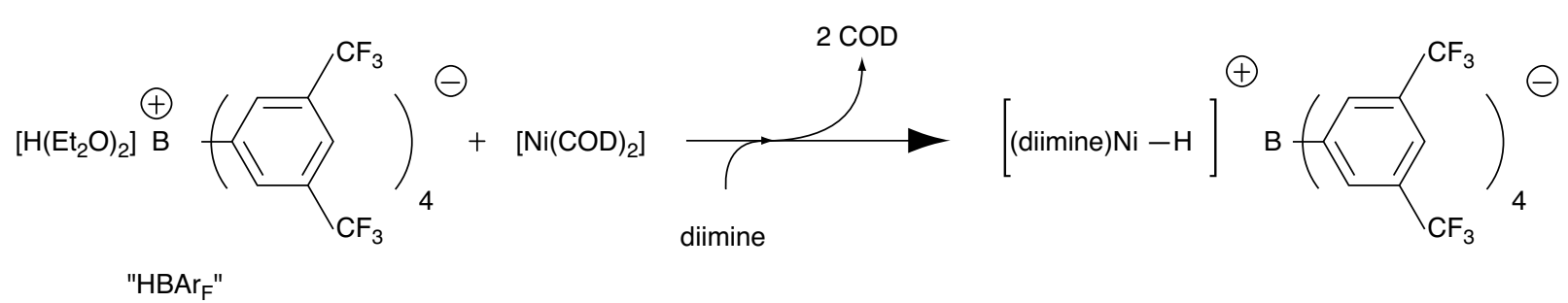

Figure 6

Activation of a $\mathrm{Ni}(0)$ precursor with an acid. 


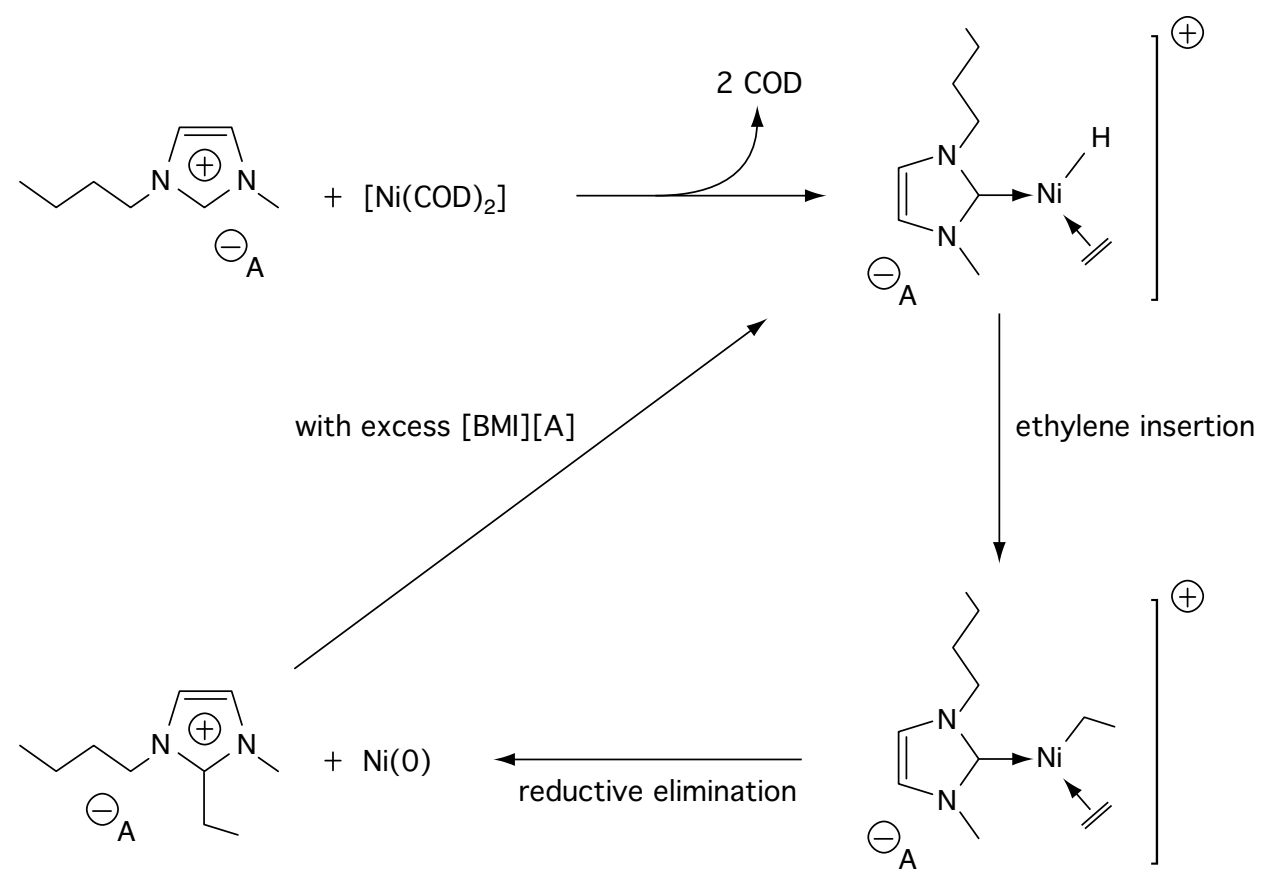

Figure 7

Formation of N-heterocyclic carbene during activation of $\mathrm{Ni}(0)$ complex.

elimination allows the recovery of the alkylated imidazolium cation (Fig. 7). An identical mechanism was also proposed by Clement and Cavell [18].

The high activity and stability of the system $\mathrm{Ni}(\mathrm{COD})_{2} / \mathrm{HBAr}_{\mathrm{F}} /[\mathrm{BMI}]\left[\mathrm{SbF}_{6}\right]$ allow us to study its recycling ability. A solution of $\mathrm{Ni}(\mathrm{COD})_{2}(0.1 \mathrm{mmol})$ in $5 \mathrm{~mL}$ of toluene is first injected in the reactor under ethylene atmosphere, and then the acid $\operatorname{HBAr}_{\mathrm{F}}(0.1 \mathrm{mmol})$ in $5 \mathrm{~mL}$ of ionic liquid. The reactor is pressurized at 28 bar at room temperature and magnetically stirred. At the end of the first $30 \mathrm{~min}$ batch, the gas phase is recovered through a flowmeter, the stirring is stopped and the organic phase of the biphasic system recovered by canula under ethylene pressure. Once the organic phase recovered, the reactor is pressurized again for a new run. After three runs, the gas and liquid phases are treated as previously described. The oligomerization can be carried out without significant deactivation as shown in Figure 8. The product distribution is not affected by the recycling of the catalytic system (Tables 7, 8).

As in one single phase homogenous system, variation of the nickel structure by introducing diimine ligands, has a significant effect on the product selectivity. Polyethylene is the major product when the $\alpha$-diimine has sterically bulky ortho aryl substituents (e.g. L2 ligand, Fig. 9). With diimine lack- ing aryl substituents, (e.g. L3 and L1 ligands, Fig. 9), C4-C8 oligomers are mainly produced. In $[\mathrm{BMI}]\left[\mathrm{SbF}_{6}\right]$, with $\mathbf{L} \mathbf{3}$ (Entry 9, Table 9), high butene selectivity is obtained with $60 \%$ 1-butene.

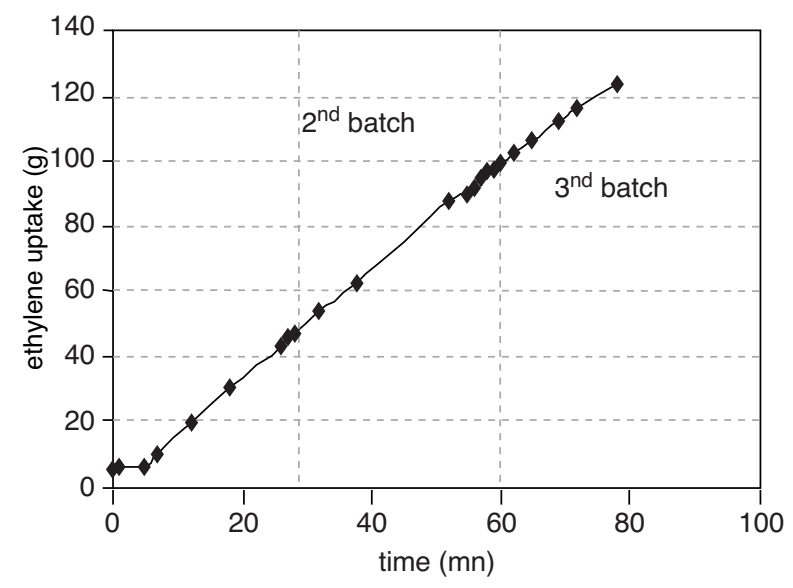

Figure 8

Ethylene oligomerization with $\mathrm{Ni}(\mathrm{COD})_{2} / \mathrm{H}_{(}\left(\mathrm{Et}_{2} \mathrm{O}\right)_{2} \mathrm{BAr}_{\mathrm{F}}$ in $[\mathrm{BMI}]\left[\mathrm{SbF}_{6}\right]$. Recycling experiments. 
TABLE 7

Recycle experiments of $\mathrm{Ni}(0) / \mathrm{H}\left(\mathrm{Et}_{2} \mathrm{O}\right)_{2} \mathrm{BAr}_{\mathrm{F}} /[\mathrm{BMI}]\left[\mathrm{SbF}_{6}\right]$ system

\begin{tabular}{|c|c|c|c|c|c|c|c|}
\hline \multirow{2}{*}{ Entry } & \multirow{2}{*}{ Cycle } & \multirow{2}{*}{$\begin{array}{l}\text { Activity TOF } \\
\left(\mathrm{g} \mathrm{C}_{2}=/ \mathrm{g} \text { Ni.h }\right)\end{array}$} & \multicolumn{4}{|c|}{ Product distribution (wt\%) } & \multirow{2}{*}{$\begin{array}{r}\alpha \text {-olefin } \\
(\mathrm{wt} \%)^{\mathrm{a}}\end{array}$} \\
\hline & & & $\mathrm{C} 4$ & C6 & C8 & C10 & \\
\hline 1 & 1 & 17201 & 53 & 34 & 9 & 2 & 26 \\
\hline 2 & 2:recycle of 1 & 17064 & 63 & 29 & 7 & 1 & 26 \\
\hline 3 & $3:$ recycle of 2 & 16040 & 60 & 33 & 6 & 0 & 32 \\
\hline
\end{tabular}

Reaction conditions: $P=28$ bar, $T=20^{\circ} \mathrm{C}, \mathrm{Ni}(\mathrm{COD})_{2}: 0.1 \mathrm{mmol}$; $\mathrm{HBAr}_{\mathrm{F}}: 0.1 \mathrm{mmol}$, biphasic system with $5 \mathrm{~mL}$ ionic liquid [BMI][SbF$\left.]_{6}\right]$ and $5 \mathrm{~mL}$ toluene, $t=30 \mathrm{~min}$ for each cycle.

${ }^{\mathrm{a}} \mathrm{Wt} \%$ of 1-butene in $\mathrm{C} 4$ fraction, remainder is 2-butene.

TABLE 8

Distribution of the C6 isomers obtained in Table 7

\begin{tabular}{|c|c|c|c|c|c|c|c|c|}
\hline Entry & & & & & & & Linear & Branched \\
\hline 1 & 5 & 5 & 3 & 10 & 35 & 44 & 48 & 52 \\
\hline 2 & 4 & 4 & 8 & 10 & 32 & 44 & 45 & 56 \\
\hline 3 & 4 & 5 & 10 & 11 & 31 & 40 & 47 & 54 \\
\hline
\end{tabular}

TABLE 9

Ethylene oligomerization in ionic liquid with $\mathrm{Ni}(0)$ precursor activated with Brönsted $\mathrm{H}\left(\mathrm{Et}_{2} \mathrm{O}\right)_{2} \mathrm{BAr}_{\mathrm{F}}$ acid

\begin{tabular}{|c|c|c|c|c|c|c|c|c|c|}
\hline \multirow{2}{*}{ Entry } & \multirow{2}{*}{ Ligand } & \multirow{2}{*}{ Solvent } & \multirow{2}{*}{$\begin{array}{l}\text { Time } \\
(\min )\end{array}$} & \multirow{2}{*}{$\begin{array}{l}\text { Activity TOF } \\
\left(\mathrm{g} \mathrm{C}_{2}=/ \mathrm{g} \text { Ni.h }\right)\end{array}$} & \multicolumn{4}{|c|}{ Product distribution (wt $\%$ ) } & \multirow{2}{*}{$\begin{array}{c}\alpha \text {-olefin } \\
(\mathrm{wt} \%)^{\mathrm{b}}\end{array}$} \\
\hline & & & & & $\mathrm{C} 4$ & $\mathrm{C} 6$ & $\mathrm{C} 8$ & $\mathrm{C} 10$ & \\
\hline 1 & no & Toluene $^{\mathrm{a}}$ & 110 & 170 & 98 & 2 & 0 & 0 & \\
\hline 2 & no & {$[\mathrm{BMI}]\left[\mathrm{NTf}_{2}\right]$} & 40 & 4000 & 60 & 35 & 5 & 0 & 33 \\
\hline 3 & no & $\left.[\mathrm{BMPy}] \mathrm{NTf}_{2}\right]$ & 30 & 1400 & 61 & 33 & 5 & 1 & 37 \\
\hline 4 & no & {$[\mathrm{BMI}]\left[\mathrm{PF}_{6}\right]$} & 130 & 500 & 94 & 6 & 0 & 0 & 34 \\
\hline 5 & $\mathrm{no}^{\mathrm{c}}$ & {$[\mathrm{BMI}]\left[\mathrm{SbF}_{6}\right]$} & 100 & 12000 & 64 & 29 & 5 & 2 & 34 \\
\hline 6 & $\mathbf{L 1}$ & {$[\mathrm{BMI}]\left[\mathrm{NTf}_{2}\right]$} & 30 & 2200 & 57 & 15 & 9 & 7 & 45 \\
\hline 7 & L1 & {$[\mathrm{BMI}]\left[\mathrm{SbF}_{6}\right]$} & 40 & 2000 & 28 & 23 & 17 & 5 & 60 \\
\hline 8 & $\mathbf{L 2}$ & {$[\mathrm{BMI}]\left[\mathrm{NTf}_{2}\right]$} & 20 & 2500 & 3 & \multicolumn{4}{|c|}{$97 \%$ polyethylene } \\
\hline 9 & $\mathbf{L 3}$ & {$[\mathrm{BMI}]\left[\mathrm{SbF}_{6}\right]$} & 20 & 1500 & 80 & 13 & 4 & 2 & 60 \\
\hline
\end{tabular}

Reaction conditions: $P=28$ bar, $T=25^{\circ} \mathrm{C}, \mathrm{Ni}: 0.1 \mathrm{mmol}$; biphasic system with $5 \mathrm{~mL}$ ionic liquid and $5 \mathrm{~mL}$ toluene.

${ }^{\text {a }} \mathrm{Ni}: 0.2 \mathrm{mmol}$, toluene $10 \mathrm{~mL}$.

${ }^{\mathrm{b}} \mathrm{Wt} \%$ of 1-butene in $\mathrm{C} 4$ fraction, remainder is 2-butene.

${ }^{\mathrm{c}}$ Catalyst-phase has been recycled 3 times with no change in reaction performances.

${ }^{\mathrm{d}} \mathrm{Ni}: 0.05 \mathrm{mmol}$. $\mathrm{HBAr}_{\mathrm{F}}$ : $0.05 \mathrm{mmol}$. L1: $0.05 \mathrm{mmol}$. 


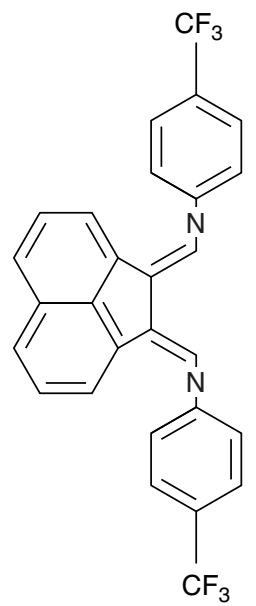

L1<smiles>CC(C)c1cccc2c1N=C(C1=Nc3c(C(C)C)cccc3C(C)C1)CC2C</smiles>

L2

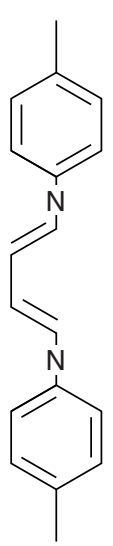

L3
Figure 9

Alpha-diimine ligands used in catalytic experiments (Table 9).

\section{CONCLUSION}

Nickel complexes associated with diimine ligands and activated with MAO are more active for the oligomerization of ethylene in biphasic chloroaluminate ionic liquid systems than in homogeneous toluene one. The reaction selectivity can be tuned in ionic liquids either towards light olefins (C4C8) or towards polyethylene according to the bulkiness of the diimine ligand. Nickel active catalysts can also be generated from $\mathrm{Ni}(0)$ and $\mathrm{HBAr}_{\mathrm{F}}$ Brönsted acid in ionic liquids such as $[\mathrm{BMI}]\left[\mathrm{NTf}_{2}\right]$ or $[\mathrm{BMI}]\left[\mathrm{SbF}_{6}\right]$. Contrary to organic solvents, the ionic liquid is able to stabilize and immobilize the $\mathrm{Ni}$ active species even in the absence of coordinative ligand, leading to high active systems. High selectivities towards C4C8 olefins can be obtained. The ionic liquid phase containing the catalyst can be recycled and reuse after decantation and separation of the reaction products.

\section{REFERENCES}

1 Olivier-Bourbigou H., Saussine L. (2002) Dimerization and Codimerization, in Applied Homogeneous Catalysis with Organometallic Compounds, Vol. 1, Cornils B., Herrmann W.A. (eds.), Wiley-VCH, Weinheim, pp. 253-265.
2 Vogt D. (2002) Oligomerization of Ethylene to Higher Linear $\alpha-$ olefins, in Applied Homogeneous Catalysis with Organometallic Compounds, Vol. 1, Cornils B., Herrmann W.A. (eds.), WileyVCH, Weinheim, pp. 240-251.

3 Lappin G.R., Sauer J.D. (1989) Alpha Olefins Application Handbook, Dekker, New York.

4 (a) Olivier-Bourbigou H., Chodorge J.A., Travers P. (1999) PTQ, Autumn, 141-149; (b) Brüll R., Meyer W., Raubenheimer H. (1998) S. Afr. J. Chem. 51, 73-78; (c) Nomura K. (1998) Recent Res. Devel., Pure Appl. Chem. 2, 473-513; (d) Dixon J., Green M., Hess F., Morgan D. (2004) J. Organomet. Chem. 689, 3641-3668.

5 (a) Braunstein P., Saussine L., Speiser F. (2005) Account Chem. Res. 38, 784-792; (b) Ajellal N., Kuhn M.C.A., Boff A.D.G., Horner M., Thomas C.M., Carpentier J.-F., Casagrande O.L. (2006) Organometallics 25, 1213-1216.

6 (a) Gibson V., Spitzmesser S. (2003) Chem. Rev. 103, 283-315; (b) Killian C., Johnson M., Brookhart M. (1997) Organometallics 16, 2005-2007.

7 Olivier-Bourbigou H., Magna L. (2002) J. Mol. Catal. 182-183, 419-437.

8 (a) Chauvin Y., Guibard I., Gilbert B. (1990) J. Chem. Soc. Chem. Commun., 1715-1716; (b) Chauvin Y., Di Marco-Van Tiggelen F., Olivier H. (1993) J. Chem. Soc. Dalton Trans. 7, 1009-1011; (c) Chauvin Y., Einloft S., Olivier H. (1995) Ind. Eng. Chem. Res. 34, 4, 1149-1155.

9 Favre F., Forestière A., Hugues F., Olivier-Bourbigou H., Chodorge, J.A. (2005) Oil Gas-Eur. Mag. 2, 83-87.

10 (a) Einloft S., Dietriech F., de Souza R., Dupont, J. (1996) Polyhedron 15, 2257-3259; (b) Pinheiro M.F., Mauler R.S., de Souza R.F. (2001) Macromol. Rapid Comm. 22, 425-428; (c) Bernardo-Gusmão K., Trevisan Queiroz L., de Souza R., Leca F., Loup C., Réau R. (2003) J. Catal. 219, 59-62.

11 (a) Wasserscheid P., Hilgers C., Keim W. (2004) J. Mol. Catal. A, 83-90; (b) Wasserscheid P., Gordon C.M., Hilgers C., Muldoon M.J., Dunkin I.R. (2001) Chem. Commun., 1186-1187.

12 Cotton F.A. (1971) Inorg. Synth. 13, 160.

13 Pernak J., Czepukowicz A. (2001) Ind. Eng. Chem. Res. 40, 2379-2383.

14 Reger D.L., Wright T.D., Little C.A., Lamba J.J.S., Smith M.D. (2001) Inorg. Chem. 40, 3810-3814.

15 (a) Johnson L.K., Killian C.M., Brookhart M. (1995) J. Am. Chem. Soc. 117, 23, 6414-6415; (b) Johnson L.K., Killian C.M., Arthur S.D., Feldman J., McCord E.F., McLain S.J., Kreutzer K.A., Benett M.A., Coughlin E.B., Ittel S.D., Parthasarathy A., Tempel D.J., Brookhart M. (1996) (E.I. Du Pont De Nemours And Company, University of North Carolina at Chapel Hill), W09623010.

16 Williams D., Stoll M., Scott B., Costa D., Oldham W. (2005) Chem. Commun., 1438-1440.

17 FAB mass spectra of the ionic liquid after catalysis gave a peak at 139.2 corresponding to the molar mass of BMI cation and a peak at 167.2 corresponding to the molar mass of 1-butyl-2ethyl-3-methylimidazolium cation.

18 Clement N.D., Cavell K.J. (2004) Angew. Chem. Int. Edit. 43, 3845-3847.

Final manuscript received in August 2007 